\title{
BUDE SQUEEZE-OUT NA KAPITÁLOVOM TRHU EFEKTÍVNEJŠÍ? (POOHLIADNUTIE SA ZA OSTATNOU REGULÁCIOU PRÁVA VÝKUPU) ${ }^{1}$
}

\section{SHALL THE SQUEEZE-OUT BE MORE EFFECTIVE? (LOOK BACK AT RECENT REGULATION ON SQUEEZE-OUT)}

\author{
Lubomír Čunderlik \\ Univerzity Komenského v Bratislave, Právnická fakulta \\ https://doi.org/10.33542/SIC2019-2-04
}

\begin{abstract}
ABSTRAKT
Právo výkupu (squeeze-out) je právnym inštitútom sledujúcim ekonomické záujmy akcionárov. Svojou právnou povahou je jeho regulácia predmetom viacerých právnych odvetví: práva kapitálového trhu sohladom na predmet práva výkupu, ktorým sú investičné tituly obchodované na transparentných kapitálových trhoch pod verejným dohladom, práva obchodných spoločností (akciového práva s dôrazom na ochranu menšinových akcionárov) a koncernového práva. V článku sa autor zameriava na vybrané problémy práva výkupu. Opiera sa o viaceré akademické názory, pričom neopomína reflektovat' realitu kapitálového trhu. Článok sa zaoberá zdôvodnením existencie tohto inštitútu a identifikáciou jeho nedostatkov v národnej právnej úprave (vzákone ocenných papieroch a investičných službách).
\end{abstract}

\begin{abstract}
The squeeze-out is a legal institution pursuing the economic interests of shareholders. By its legal nature, its regulation is subject to several fields of law: capital market law (with respect to the subject of the buy-out right, which are investment titles traded on transparent capital markets under public supervision), company law (law on shares emphasizing the protection of minority shareholders) and law of corporate groups. In the article, the author focuses on selected issues of squeeze-out. He relies on academic opinions and tries to reflect the reality of the capital market as well. The article deals with the justification of the existence of this institute and the identification of its shortcomings in the national legislation (in the Securities and Investment Services Act).
\end{abstract}

\section{I. ÚVOD}

O práve výkupu (tzv. pravý squeeze-out, buy-out) toho bolo ako o kontroverznom nástroji vytlačenia menšinových akcionárov popísané svojho času (najmä v čase po nie vždy

\footnotetext{
Článok bol spracovaný ako výstup v rámci riešenia projektu VEGA 1/0440/17 s názvom „Inovatívne formy tvorby peňažných fondov a ich prevodov“".
} 
optimálnej transpozícii príslušných európskych aktov) už mnoho. ${ }^{2} \mathrm{~V}$ článku sa síce dotkneme niektorých už skôr opakovane analyzovaných oblastí, avšak jeho ciel'om je predovšetkým poukázat' na vybrané substantívne zmeny a ich podstatu, ktoré nastali v právnej úprave tohto inštitútu práva kapitálového trhu. ${ }^{3}$ Dňa 1 . januára 2019 nadobudli účinnost' ustanovenia, ktoré nanovo upravili reguláciu práva výkupu obsiahnutú v § 118i zákona č. 566/2001 Z. Z. o cenných papieroch a investičných službách a o zmene a doplnení niektorých zákonov (zákon o cenných papieroch) v znení neskorších predpisov (d’alej len „ZoCP“). Ide o ustanovenia zákona č. 373/2018 Z. z., ktorým sa mení a dopĺńa zákon č. 371/2014 Z. z. o riešení krízových situácií na finančnom trhu a o zmene a doplnení niektorých zákonov v znení neskorších predpisov a ktorým sa menia a dopĺñajú niektoré zákony, medzi inými aj ZoCP (novelizačným čl. VI). ${ }^{4}$

Podl'a osobitnej časti dôvodovej správy k návrhu uvedeného zákona má íst' „o úpravu, ktorej ciel’om je zjednodušit' proces výkupu (squeeze out) zmenou procesu (v súčasnosti režim prevodu t. j. zmluvnou formou za účasti oboch strán), kde sa navrhuje prejst' na systém prechodu (na základe rozhodnutia valného zhromaždenia), nakol'ko súčasné znenie zákona o cenných papieroch neumožňuje efektívne zrealizovanie práva výkupu v prospech akcionára, ktorý má majoritný podiel presahujúci 95\% v akciovej spoločnosti. Táto situácia komplikuje fungovanie akciových spoločností s majoritným akcionárom, ktorého podiel na základnom imani a hlasovacich právach presahuje uvedenú hranicu 95\% a zvyšuje náklady fungovania takýchto spoločností." Uvedená legislatívna zmena spôsobu vytesnenia minoritných akcionárov je východiskom skúmanej problematiky, a je o to zaujímavejšia, že v niektorých štátoch (napríklad Česká republika) bol tento spôsob vytesnenia upravený prakticky od okamihu transpozície príslušnej smernice, a to smernice Európskeho parlamentu a Rady 2004/25/ES z 21. apríla 2004 o ponukách na prevzatie (d’alej len „smernica o ponukách prevzatia“). V nadväznosti na to možno nájst' viacero diskusných článkov aj s protichodnými názormi, zdôrazňujúcimi znaky vyvlastnenia. ${ }^{5}$ Autor sa $v$ článku zamýšl’a v nadväznosti na recentnú reguláciu nad efektivitou prijatých zmien a ich legitimitou v optike fungovania mechanizmu kapitálového trhu. Ťažiskovými metódami spracovania sú metóda syntézy, názorovej konfrontácie a analýzy.

\section{VÝCHODISKÁ REGULÁCIE PRÁVA VÝKUPU}

\section{Motívy zavedenia vytesnenia menšinových akcionárov}

Viaceré motívy pre existenciu vytesnenia sa v zásade v odbornej literatúre zhodujú a nepredstavujú sporný prvok, na rozdiel od základnej otázky, či squeeze-out zaviest' alebo

2 Za všetky v ČR pozri napríklad HAVEL, B.: Vyvlastnění, vytlačení akcionářů a ústavnost. In: Právní rozhledy, 2006, č. 6, s. 215-220. ČECH, P.: K (četným) problémům právní úpravy výkupu účastnických cenných papíru (squeeze-out). In: Právní rozhledy, 2005, č. 18, s. 651-663. Na Slovensku ide iba o niekolko analytických článkov, najmä GLÉZL, A. JABLONKA, B. - PATAKYOVÁ, M.: Úprava práva výkupu (squeeze-out) v slovenskom práve (dodržanie princípu efektívnosti komunitárneho práva a ústavné aspekty práva výkupu). In: Vzájemné ovlivňování komunitární úpravy českého a slovenského obchodního práva na pozadí procesu jejich reforem : Sborník ze setkání kateder obchodního práva právnických fakult České republiky a Slovenské republiky. Praha : Univerzita Karlova v Praze, Právnická fakulta, 2007, s. 223-233.

3 Teória práva finančného trhu, prípadne rozvinutého práva kapitálového trhu zarad’uje squeeze-out do regulácie trhového správania na kapitálovom trhu alebo do regulácie výstupu (exitu) z trhu, pričom úzko súvisí s právom prevzatia (Übernahmerecht), respektíve s inštitútom ponuky na prevzatie (take over bid). K prvému zaradeniu pozri napríklad LANGENBUCHER, K.: Aktien- und Kapitalmarktrecht. 2. Auflage. München : Verlag C. H. Beck, 2011, s. 423 a nasl. ISBN 978-3-406-62494-0, k druhému zaradeniu pozri ČUNDERLÍK, L. a kol.: Právo finančného trhu. Bratislava : Wolters Kluwer, s.r.o., 2017, s. 90, 93-95. ISBN 978-80-8168-753-2, BUCK-HEEB, P.: Kapitalmarktrecht. 2. Auflage. Heidelberg : C. F. Müller Verlag, 2007, s. 191 a nasl. ISBN 978-3-8114-8055-1.

4 Dostupné elektronicky na https://www.nrsr.sk/web/Default.aspx?sid=zakony/zakon\&MasterID=6986 [navštívené 28.4.2019].

5 Pozri napríklad spomenuté články od Havla a Čecha v poznámke pod čiarou č. 2. 
nie, a to bez ohl'adu na množstvo alebo povahu jeho motívov. Dôvodom spornosti je principiálne sledovanie takmer výlučne ekonomickej efektívnosti akciových spoločností s ciel’om zvýšenia ich konkurenčnej schopnosti, čo je celospoločensky účelné. Medzi najčastejšie spomínané motívy sa zarad'ujú

a) znižovanie správnych nákladov, ktoré nie sú úmerné prínosu menšinových akcionárov (náklady na publicitu, konanie valných zhromaždení) a zjednodušenie systému riadenia (prekonaním zneužitia postavenia menšinových akcionárov), ktorých ciel'om je znížit' administratívnu zát'až (súhrnne ako agency costs), racionalizácia flexibility rozhodovania (zvýšenie kvality riadenia), rozvoj emitenta podl'a predstáv väčšiny, zmena dividendovej politiky a iné operatívno-ekonomické ciele,

b) premena verejnej akciovej spoločnosti na súkromnú (going private) rozhodnutím väčšinového akcionára o odchode $\mathrm{z}$ regulovaného trhu,

c) eliminácia konfliktu medzi materskou a dcérskou spoločnost’ou,

d) umožnenie speňaženia nelikvidnej investície akcionárskej menšine,

e) podpora aktivity v oblasti fúzií a akvizícií a trhu korporátnej kontroly,

f) odstránenie dedičstva nepodarenej kupónovej privatizácie ${ }^{6}$ (v ČR boli zrealizované v nadväznosti na to stovky squeeze-outov).

Osobitná čast' dôvodovej správy k § 118i ZoCP k zákonu č. 644/2006 Z. z. (ktorým bol tento inštitút zavedený do právneho poriadku SR) navyše uvádza, že možnost' minoritného investora ovplyvnit' výnos $\mathrm{z}$ investície je iba teoretická, pričom záujem na efektívnejšom fungovaní spoločnosti možno všeobecne považovat' za dôležitejší ako záujem minoritných akcionárov zotrvávat' v spoločnosti bez možnosti reálne ovplyvnit' chod spoločnosti a s malou nádejou na efektívne zhodnotenie účasti v budúcnosti. V zmysle tejto argumentácie by právo výkupu malo byt' spravodlivým spôsobom vyvažovania práv akcionárov, spomedzi ktorých má mat' väčšiu váhu vlastnícke právo väčšinového akcionára, ktorý nesie prevažné riziká podnikania spoločnosti.

Možnost' optimálne usmernit' riadenie spoločnosti vychádza aj z reálnej (nielen teoreticky deklarovanej) znalosti akcionárov o hospodárskom sektore pôsobenia spoločnosti. Uzsák v súvislosti s tým uvádza, že manažéri vedia, ako vyzerá trh s produktom spoločnosti, či má potenciál rást' alebo aká bude návratnost' realizovaných investícií, akcionári tieto informácie $\mathrm{k}$ dispozícii nemajú s výnimkou ovládajúceho akcionára, ktorý deleguje manažment. Jeho dôverná znalost' potom umožňuje načasovat' rozhodnutie o realizácii squeeze-outu. Súhrn spomenutých motívov má byt' natol'ko presvedčivý, že právo výkupu sa ukazuje ako racionálny nástroj a musí byt' uvítané prinajmenšom tými, ktorým má primárne slúžit', t. j. spoločnostiam s rastovou stratégiou. ${ }^{7}$

\section{Právne východiská a ich súvislosti}

Regulácia práva výkupu (ako tento inštitút pozná náš právny poriadok) bola do nášho právneho prostredia prevzatá s účinnost'ou od 1. januára 2007 z európskej právnej úpravy, obsiahnutej v spomenutej smernici o ponukách prevzatia, zákonom č. 644/2006 Z. z., ktorým sa novelizoval ZoCP tým, že sa do jeho textu doplnil nový § 118i. Smernica predstavuje len

6 Spracované podl’a HEČKOVÁ, J. - CHAPČÁKOVÁ, A.: Explikácia významu inštitútu Squeeze Out v podmienkach Slovenskej republiky. In: Ekonomický časopis, roč. 57, 2009, č. 5, s. 425, 427 a 428, UZSÁK, M.: Co se o squeezeout(u) nepíše. In: Bulletin advokacie, 2007, č. 3, s. 16-17, ČUNDERLÍK, Právo finančného trhu, s. 93-94, KOTÁSEK, J.: Vytěsnění anonymního akcionáře. In: Časopis pro právní vědu a praxi, roč. XIV, 2006, č. 3, s. 258.

7 UZSÁK, Čo se o squeeze-out(u) nepíše, s. 17 a 20. Podobne UŽÁKOVÁ, V.: Constitutional and Legal Aspects of Squeeze-out of Minority Shareholders. In: Mílniky práva v stredoeurópskom priestore 2012 : Zborník príspevkov z medzinárodnej konferencie. Bratislava : PraF UK, 2012, s. 966. 
minimálny štandard harmonizácie $\mathrm{v}$ tejto oblasti, čo je typické pre celú reguláciu kapitálového trhu v období po roku 2000 a vyplýva zo skutočnosti, že squeeze-out bol vel'mi rozšírený inštitút známy v mnohých členských štátoch EÚ. ${ }^{8}$ Smernica o ponukách prevzatia upravuje tento inštitút výlučne v jedinom článku (čl. $15 \mathrm{~s}$ do určitej miery zavádzajúcim nadpisom v slovenskej jazykovej verzii „Právo na odpredaj“, čo môže navádzat' k jeho náprotivku označovanému ako sell-out) a podrobnejšiu právnu úpravu prenecháva na transponujúce členské štáty. Squeeze-out vecne súvisí s predchádzajúcou realizáciou ponuky na prevzatie a z tohto dôvodu sa principiálne smernica o ponukách prevzatia má vzt'ahovat' na tie ciel'ové spoločnosti (emitentov), ktorých prevoditel'né cenné papiere, s ktorými sú spojené hlasovacie práva, sú prijaté na obchodovanie na regulovanom trhu $\mathrm{v}$ jednom alebo viacerých členských štátoch (tzv. multi-listing). ${ }^{9}$ Článok 15 pritom ustanovil len rámcové základné podmienky uplatnenia práva výkupu: a) vlastníctvo aspoň 90\% takých cenných papierov, s ktorými je spojených $90 \%$ hlasovacích práv (pričom členské štáty mohli využit' národnú vol'bu zvýšenia tohto prahu do $95 \%$ vrátane), b) lehotu troch mesiacov (od uplynutia lehoty na prijatie ponuky na prevzatie) na uplatnenie práva výkupu, c) garanciu tzv. primeranej ceny pre zostatkových (menšinových) vlastníkov uvedených cenných papierov.

Podl'a osobitnej časti dôvodovej správy k § 118i k zákonu č. 644/2006 Z. z. je účelom práva výkupu „reagovat' na prípady, kedy vakciovej spoločnosti dôjde ktakej zmene pomerov, pri ktorej sa pôvodne rozptýlená akcionárska štruktúra zmení v koncentrovanú. Sústredením podstatnej časti podielov v rukách majoritného akcionára dochádza $k$ strate funkčnosti vnútorných mechanizmov akciovej spoločnosti. (...) Situácia, ktorá môže nastat', sa nezlučuje so zmyslom existencie akciovej spoločnosti ani soprávnenými očakávaniami všetkých investorov. Z týchto dôvodov umožňuje väčšina právnych poriadkov väčšiny členských štátov EÚ reštrukturalizáciu spoločnosti z verejnej na súkromnú formou inštitútu práva výkupu ako opatrenie, z ktorého majú prospech majoritni aj minoritní akcionári. "10

ZoCP v rozsahu pôsobnosti kopíruje smernicu o ponukách prevzatia a právo výkupu viaže na cenné papiere regulovaných emitentov - tie obchodné spoločnosti, ktorých akcie sú prijaté na obchodovanie na regulovanom trhu v Slovenskej republike alebo v inom členskom štáte, a teda ide o verejné akciové spoločnosti (pozri $\S 114$ ods. 1 čast' vety za bodkočiarkou). Majoritný akcionár môže podla $\S 118 \mathrm{i}$ ods. 1 ZoCP právo výkupu uplatnit' v prípade, ak je majitel’om akcií, ktorých súhrnná menovitá hodnota predstavuje najmenej 95\% základného imania, s ktorým sú spojené hlasovacie práva a s ktorými je súčasne spojený najmenej 95\% podiel na hlasovacích právach v emitentovi. ${ }^{11}$ Predpokladom zrealizovania práva výkupu je predchádzajúca povinná alebo dobrovol’ná ponuka na prevzatie, ktorá nebola čiastočná ani podmienená. Tieto podmienky zostali nezmenené $\mathrm{v}$ ostatnej právnej úprave práva výkupu účinnej od 1. januára 2019.

Ked’že je ponuka na prevzatie conditio sine qua non pre uplatnenie práva výkupu, považujeme za samozrejmé, že derivatívne sa základné princípy právnej úpravy ponuky na prevzatie (obsiahnuté v identickej smernici o ponukách prevzatia) aplikujú primerane aj na squeeze-out, konkrétne ide o zásadu rovnakého zaobchádzania s majitel'mi cenných papierov, zásadu primeraného času a informovanosti na prijatie rozhodnutia týkajúceho sa ponuky,

\footnotetext{
DOLEŽIL, T. - HAVEL, B.: Squeeze-out trochu jinak. In: Jurisprudence, roč. XIV, 2005, č. 8, s. 12.

Pozri čl. 1 ods. 1 v spojení s čl. 15 ods. 1 smernice o ponukách prevzatia.

Dostupné v informačnom systéme ASPI.

11 Do podielu väčšinového akcionára na hlasovacích právach sa zarátavajú aj hlasovacie práva spojené s akciami držanými tret'ou osobou, ak medzi väčšinovým akcionárom a touto tret'ou osobou existuje písomná zmluva ohladne trvalého spoločného postupu riadenia ciel'ovej spoločnosti prostredníctvom spoločného výkonu hlasovacích práv, alebo ak tretia osoba vykonáva hlasovacie práva na pokyn a v prospech väčšinového akcionára podl'a zmluvy o výkone hlasovacích práv. HEČKOVÁ - CHAPČÁKOVÁ, Explikácia významu inštitútu Squeeze Out v podmienkach Slovenskej republiky, s. 427.
} 
zásadu konania štatutárneho orgánu v záujme celej spoločnosti, zásadu zákazu umelého ovplyvňovania trhovej ceny, zásadu uspokojenia nárokov a zásadu neprekážania činnosti ciel'ovej spoločnosti. ${ }^{12} \mathrm{Z}$ uvedeného akcentujeme najmä zásadu nediskriminácie a zásadu zabezpečenia nárokov.

Pôvod vecného súvisu ponuky na prevzatie s právom výkupu nachádzame v ekonomickom procese tvorby koncernu. Vznik koncernu vedie kzmene účelu spoločnosti s potrebou ochrany investície menšinového spoločníka. Menšinový spoločník by mal mat možnost' kvalifikovane sa rozhodnút' o zotrvaní v spoločnosti s možnost'ou odkúpenia jeho podielu v prípade neprijatia zvýšeného rizika po začlenení akciovej spoločnosti do koncernu. ${ }^{13}$ Ponuka na prevzatie preto sleduje tiež ochranu menšinových akcionárov.

Na základe uvedeného tak môžeme tvrdit', že založenie koncernu historicky podnietilo tlak na zvýšenú ochranu minoritných akcionárov, a to aj prostredníctvom práva výkupu, paradoxne napriek tomu, že tento inštitút je právne skôr vnímaný ako ich obmedzovanie v budúcej dispozícii s ich akciami.

\section{III. (NE)KONTROVERZNÝ SQUEEZE-OUT}

\section{Dôvody, prečo sa právo výkupu považuje za kontroverzné}

Uplatnenie práva výkupu je kontroverzne vnímané predovšetkým v odborných kruhoch právnickej obce. Dôvody, ktoré vzbudzujú pochybnosti, vyplývajú jednak zo zavedenia samotného inštitútu (jeho podstaty) a jednak z jeho konkrétnej právnej úpravy, ${ }^{14}$ ktorá má byt' garanciou ochrany práv minoritných akcionárov.

Právo výkupu per se indikuje expropriáciu (vyvlastnenie), a preto zvykne byt' právne posudzované z tohto pohl'adu v rovine ústavnoprávnej. $\mathrm{V}$ tejto súvislosti bolo posudzované vo viacerých členských štátoch EÚ už v časoch pred prijatím smernice o ponukách prevzatia. Aj ked' bol tento inštitút $\mathrm{v}$ niektorých štátoch pri jeho zavedení rozporovaný $\mathrm{z}$ hl'adiska súladu $\mathrm{s}$ ústavnými princípmi, vždy súdy dospeli k záveru, že tento inštitút nie je v rozpore $\mathrm{s}$ ústavami daných štátov (napríklad rozhodnutie nemeckého Spolkového ústavného súdu sp. zn. 1 BvL 16/60 vo veci Feldmühle zo 7. augusta 1962). ${ }^{15}$ V Českej republike bol jeho súlad s ústavou posudzovaný po transpozícii smernice (pozri nález Ústavného súdu ČR Pl. ÚS 56/05 z 27. marca 2008; ústavný súd zaujal stanovisko, že nejde o vyvlastnenie, ale o určitý spôsob usporiadania majetkových vzt’ahov aprobovaný štátom ${ }^{16}$ ).

Vyvlastnenie ako inštitút verejného práva je možné uplatnit' podl’a čl. 20 ods. 4 Ústavy SR iba: 1. v nevyhnutnej miere (prostriedok ultima ratio), 2. vo verejnom záujme, 3. na základe zákona, 4. za primeranú náhradu. V rámci názorov o spornosti práva výkupu ako formy vyvlastnenia bola azda najviac diskutovanou otázka verejného záujmu. Čast'

12 ČAVOJSKÝ, P.: Základné princípy právnej úpravy ponuky na prevzatie podielu na majetkových cenných papieroch podl'a 13. smernice. In: Právny obzor, roč. 87, 2004, č. 3, s. 250-260.

13 DOLEŽIL - HAVEL, Squeeze-out trochu jinak, s. 10.

14 KADUCH, B.: Vývoj úpravy squeeze-out v Polsku a poznámky k transpozici směrnice o nabídkách převzetí. In: Dny veřejného práva : Sborník př́spěvků z mezinárodní konference. Brno: Masarykova univerzita, 2007, s. 1051.

15 Osobitná čast' dôvodovej správy k § $118 \mathrm{i}$ ZoCP k zákonu č. 644/2006 Z. z. Dostupé v informačnom systéme ASPI.

16 S nálezom polemizuje Užáková, ked’ uvádza, že o zbavení práva napríklad pri vyporiadaní spoluvlastníctva nerozhoduje jeden zo spoluvlastníkov vlastným rozhodnutím proti vôli druhého subjektu práva, ale súd. Pozri UŽÁKOVÁ, V.: Zánik účasti akcionára v akciovej spoločnosti so zameraním na squeeze out : Dizertačná práca. 2017, s. 103. Tento názor podl’a nás nezohl'adňuje právny stav režimu prechodu, ktorým štát prenáša pôsobnost' orgánu verejnej moci na orgán spoločnosti (a teda nerozhoduje spoluvlastník sám); v prípade zakotvenia rozhodovania pre orgán dohladu by k prenosu pôsobnosti dokonca ani nedochádzalo, ale by bola daná z povahy veci. Orgán dohladu by v administratívnom procese rozhodol na základe naplnenia zákonných dôvodov bez d’alšieho, ked’že by nerozhodoval spor v kontradiktórnom konaní. Zavedeniu právomoci rozhodnút' administratívne o práve výkupu sa však orgány dohl'adu môžu bránit' z dôvodu vylúčenia súdneho prieskumu v správnom súdnictve s rizikom náhrady škody. Podrobnejšie sa tomu venujeme d’alej v texte článku. 
publikovaných názorov prezentuje presvedčenie, že verejný záujem nie je možné vidiet' len v samotnej skutočnosti, že zákon právne upravil inštitút vytesnenia (alebo že absentuje vydanie individuálneho správneho aktu, čím je popretá existencia verejného záujmu ako takého), ${ }^{17}$ a teda fakticky konštatuje absenciu tejto podmienky a odmieta povahu vyvlastnenia. Na druhej strane niektoré z týchto názorov (Patakyová a kol.) však uvádzajú, či nie je vhodné, aby zákonná úprava ustanovila konkrétne dôvody verejného záujmu, po posúdení ktorých by sa rozhodlo (bez ohl'adu na rozhodujúci subjekt) o realizácii práva výkupu, alebo či by postačovalo všeobecne v zákone upravit' (konštatovat'), v čom spočíva verejný záujem (čím by podmienka verejného záujmu bola zrejme naplnená, a podl'a nášho názoru by tak následne mohla smerovat' $\mathrm{k}$ prevalencii názorov o určitom spôsobe vyvlastnenia). V tejto súvislosti poukazujeme na to, že formulácia dôvodov verejného záujmu bude podl'a nášho názoru klást' zvýšené nároky na zdôvodnenie príslušného rozhodnutia o squeeze-oute, napríklad rozhodnutia orgánu dohl'adu, rozhodnutia valného zhromaždenia, atd'. podl'a toho, ktorý orgán bude ustanovený na rozhodnutie. Povahou takéhoto rozhodnutia samotného sa venujeme v nasledujúcom texte.

Diskusiu o vyvlastnení uzaviera Havel „šalamúnsky“, ked’ uvádza, že squeeze-out je bud’ akési vyvlastnenie druhej triedy v dôsledku rozšírenia chápania vyvlastnenia vývojom, alebo možno uznat', že vyvlastnenie je inštitút nemenný, nepodliehajúci potrebám doby. ${ }^{18}$ Patakyová a kol. uvádzajú, že ,vytlačenie (vytesnenie) možno vymedzit'v ústavnoprávnom rámci za akési zdanie vyvlastnenia, pretože dôsledkom neho dochádza k rovnakému efektu zhladiska vplyvu na vlastnícke právo menšinového vlastníka akcii." "19 Nech už to pomenujeme akokol’vek, máme za to, že právo výkupu posúva hranice limitácie vlastníckeho práva originálnym smerom.

Odhliadnuc od posudzovania znakov vlastných vyvlastneniu zostáva pri ústavnej súladnosti aktuálnou otázka spravodlivosti požadovat' exit z investície od menšinových akcionárov (resp. primeranost' zásahu do ich vlastníckeho práva ${ }^{20}$ ), ktorí sa rozhodli dlhodobo (alebo z dôvodu napríklad určitej rodinnej vernosti, tradície, vedomosti o vysokej hodnote svojich akcií a pod.) držat' akcie. V tejto otázke odkazujeme na vyššie uvedené motívy zavádzania vytesnenia, ktoré majú vo svojom súhrne vytvorit' rovnováhu medzi rôznymi záujmami akcionárov. Ide o teóriu záujmov, ktoré sa medzi sebou vyvažujú podl’a implicitného verejného záujmu sledujúceho zavedenie práva výkupu. Napriek existencii verejného záujmu, obsiahnutého $\mathrm{v}$ ekonomickej racionalizácii fungovania akciovej spoločnosti, máme za to, že nejde o verejný záujem v rámci vyvlastnenia, ktorého naplnenie sa má skúmat' individuálne ad hoc, a preto nejde o expropriáciu. Ak sa aj prikloníme k spomenutému názoru o potrebe doplnenia d’alších explicitných dôvodov alebo dôvodu, ktoré by predstavovali naplnenie verejného záujmu pri realizácii squeeze-outu, išlo by podl'a nás len o d'alšie zákonné predpoklady na jeho realizáciu, ktorých splnenie by bolo potrebné identifikovat'. Stále by však nešlo o posudzovanie podl'a okolností prípadu, a teda by nešlo o vyvlastnenie.

17 Napríklad GLÉZL - JABLONKA - PATAKYOVÁ, Úprava práva výkupu (squeeze-out) v slovenskom práve (dodržanie princípu efektívnosti komunitárneho práva a ústavné aspekty práva výkupu), s. 230, k absencii správneho aktu pozri HAVEL, Vyvlastnění, vytlačení akcionářů a ústavnost, s. 218. Na rozdiel od opačného názoru o implicitnom verejnom záujme, napríklad Dědič, resp. názoru o kvalifikácii squeeze-outu ako vyvlastnenia u Užákovej. Máme za to, že prijatím zákonnej úpravy sa vždy prezumuje určitý verejný záujem na reglementácii spoločenských vzt’ahov, aj ked' nemusí byt' explicitne deklarovaný v dôvodovej správe k návrhu zákona.

18 HAVEL, Vyvlastnění, vytlačení akcionářủ a ústavnost, s. 218.

19 GLÉZL - JABLONKA - PATAKYOVÁ, Úprava práva výkupu (squeeze-out) v slovenskom práve (dodržanie princípu efektívnosti komunitárneho práva a ústavné aspekty práva výkupu), s. 229.

20 Užáková uvádza, že jednoznačne menším zásahom do práv jednotlivca by bolo obmedzenie určitých práv viažucich sa k vlastníctvu akcií. Pozri UŽÁKOVÁ, Zánik účasti akcionára v akciovej spoločnosti so zameraním na squeeze out, s. 106. 
Konštatujeme, že právo výkupu napokon nemožno vnímat’ ani ako narušenie princípu legitímnych očakávaní. Akcionári ako osoby podiel'ajúce sa na podnikaní by si mali byt' vedomí rizík spojených s vlastníctvom akcií obchodovaných na burze, pretože platí známa nevyvrátitel'ná domnienka o znalosti všetkého, čo bolo vyhlásené v zbierke zákonov (§ 15 zákona č. 400/2015 Z. z. o tvorbe právnych predpisov a o Zbierke zákonov Slovenskej republiky a o zmene a doplnení niektorých zákonov v znení neskorších predpisov).

Ak by sme squeeze-out vylúčili z režimu vyvlastnenia a abstrahovali od jeho potenciálnej neústavnosti, zostáva skúmat' primeranost' konkrétnej právnej úpravy. Ako pri každej právnej úprave regulujúcej vzájomné práva a povinnosti zmluvných strán, v ktorých má jedna z nich silnejšie a druhá slabšie postavenie (napríklad spotrebitel', obet' diskriminácie, chránený zamestnanec), tak aj pri práve výkupu je potrebné pomerovat' konkrétne práva proti sebe stojacich akcionárov, z ktorých by sme minoritného akcionára mohli kvalifikovat' postavením „slabšej (zmluvnej) strany“ v porovnaní s majoritným akcionárom, pričom v prípade režimu:

a) prevodu sú zmluvné strany menšinoví akcionári a väčšinový akcionár medzi sebou,

b) prechodu zmluvnou stranou nie sú akcionári voči sebe navzájom, ale voči obchodnej spoločnosti (ktorá - konaním valného zhromaždenia, na základe stanoviska predstavenstva a dozornej rady - rozhodne o vytesnení podl'a právnej úpravy účinnej od 1. januára 2019).

Už sme uviedli, že okrem základných (rámcových) podmienok uplatnenia práva výkupu $\mathrm{v}$ smernici o ponukách prevzatia boli viaceré detailné otázky jeho realizácie ponechané na konkrétnu národnú právnu úpravu.

Smernica o ponukách prevzatia napríklad neupravuje spôsob zmeny vlastníctva medzi majoritným a minoritnými akcionármi, ani neposkytuje návod, či má íst' o prechod alebo prevod. V Slovenskej republike sa krátko po transpozícii smernice o ponukách prevzatia objavil názor, že ,,znenie prijatej právnej úpravy práva výkupu efektívne nezabezpečuje pre dotknuté osoby možnost' vykonat' právo výkupu v prípade splnenia podmienok na jeho uplatnenie. " 21 Tento názor sa opieral o zavedenie režimu uplatnenia práva výkupu prostredníctvom prevodu cenných papierov, t. j. k nadobudnutiu cenného papiera väčšinovým akcionárom mohlo dôjst' až na základe prejavu vôle menšinového akcionára (prijatím návrhu na uzavretie zmluvy o odkúpení akcií) alebo - v prípade jeho negatívneho postoja právoplatným rozhodnutím všeobecného súdu o nahradení prejavu vôle menšinového akcionára (pozri ustanovenia $\S 118 \mathrm{i}$ ods. 1,8 a 9 ZoCP v znení účinnom do 31. decembra 2018). S tým spájajú autori uvedeného názoru tieto komplikácie efektívnej realizácie práva výkupu:

- ak menšinový akcionár s návrhom zmluvy nesúhlasí (alebo s väčšinovým akcionárom nekomunikuje ${ }^{22}$ ), získanie súdneho rozhodnutia o nahradení jeho prejavu vôle môže byt' v podmienkach Slovenskej republiky otázkou niekol'kých rokov, pričom do právoplatného rozhodnutia vo veci môže dôjst' $\mathrm{k}$ prevodu akcií na tretiu osobu,

- neexistencia jedného miestne príslušného súdu (operačný problém pri väčšom počte pasívne legitimovaných menšinových akcionároch s rôznym miestom trvalého pobytu alebo rôznym sídlom, riziko nerovnakej aplikácie práva a prípadných priet’ahov v konaní).

21 GLÉZL - JABLONKA - PATAKYOVÁ, Úprava práva výkupu (squeeze-out) v slovenskom práve (dodržanie princípu efektívnosti komunitárneho práva a ústavné aspekty práva výkupu), s. 223. Autori tiež uvádzajú, že úprava práva výkupu v slovenskom právnom poriadku bola oproti úprave českej takmer nepoužitel’ná (pozri s. 227 citovaného článku).

22 Nejasnostiam, ktoré sa objavujú pri výkupe akcií minoritných anonymných (platí pre ČR, ked’že v SR u listinných akcií forma na doručitel'a už nie je možná) a nekooperujúcich akcionárov sa venuje bližšie Kotásek, pozri KOTÁSEK, Vytěsnění anonymního akcionáře, s. 257-261. 
Na základe toho spomenutí autori konštatovali, že slovenská právna úprava efektívny proces zamýšl’aný komunitárnym právom pre uplatnenie práva výkupu pre dotknutého hlavného akcionára (navrhovatel'a) neponúka, čím nedošlo k splneniu povinnosti uskutočnit' také opatrenia, ktoré zabezpečia dosiahnutie výsledku predpokladaného v smernici o ponukách prevzatia a tým došlo $\mathrm{k}$ porušeniu princípu efektívnosti národnej právnej úpravy implementujúcej právo EÚ. ${ }^{23}$ Tomu zodpovedá aj skutočnost', že do roku 2018 vrátane bolo Národnou bankou Slovenska (NBS) udelených iba šest' súhlasov na uplatnenie práva výkupu. ${ }^{24}$ Otvorenou otázkou zostáva, do akej miery boli riziká súdneho konania a z toho vyplývajúca nefunkčnost' inštitútu práva výkupu zodpovedajúce garancii ochrany minoritných akcionárov.

Tento problém považujeme v súčasnosti už za prekonaný práve s ohl'adom na novú právnu úpravu § 118i ZoCP účinnú od 1. januára 2019. Podobne ako v Českej republike prešla slovenská právna úprava na režim prechodu vlastníctva $\mathrm{k}$ cenným papierom na základe účinnosti rozhodnutia valného zhromaždenia emitenta. Podl'a osobitnej časti dôvodovej správy k novelizačnému čl. VI zákona č. 373/2018 Z. z. „,jednou zo základných otázok, ktoré navrhovatel' (rozumej väčšinový akcionár, poznámka autora) zvažuje pri rozhodovani sa, či uplatní právo výkupu, je predpokladaná dlžka trvania celého procesu, a preto je potrebné, aby sa dĺžka trvania squeeze outu dala dopredu predvídat', čo je spolu s možnost’ou praktickej aplikácie právnej úpravy, ktorej výsledkom bude dosiahnutie ciel'a squeeze outu v reálnom časovom horizonte, základným dôvodom navrhnutého riešenia. Rozhodnutie valného zhromaždenia o prechode vlastníckeho práva akcií je zákonný spôsob umožňujúci dosiahnutie všetkých vyššie uvedených cielov, pričom právo akcionárov požiadat' súd o preskúmanie primeranosti protiplnenia ostáva zachované, nemá však ako doteraz vplyv na priebeh a ukončenie squeeze outu."

Nielen režim prevodu podliehal kritike. Aj režim prechodu rozhodnutím valného zhromaždenia, možno práve v dôsledku vyššej flexibility, vykazuje podl'a niektorých autorov z Českej republiky (napríklad Uzsák), v ktorej tento režim existoval od počiatku, znaky svojvol'ného vytesnenia hlavným akcionárom, ktorý tak zneužíva svoju hospodársku silu na vylúčenie iných hráčov z hry. V Slovenskej republike, ako bolo uvedené, je režim prechodu (rozhodnutím valného zhromaždenia) zavedený od 1. januára 2019. V nadväznosti na to je podl'a našej mienky dôležité skúmanie povahy orgánu, ktorý o vykonaní práva výkupu rozhoduje. Podl'a Havla je vytesnenie založené na rozhodnutí samotnej spoločnosti, konkrétne rozhodnutí orgánu súkromného subjektu vykonanom v rámci autonómie vôle, hoci ovplyvnené hlavným akcionárom. Z toho následne vyplýva, že absentuje d’alší znak imanentný vyvlastneniu, totiž vydanie jednostranného a konštitutívneho správneho aktu, ktorým by došlo k vyvlastneniu. Vytlačenie je tak iste zásah do vlastníckeho práva svojou podstatou súkromnoprávny, nie verejnoprávny. Tento názor súčasne spochybňuje, že by mohlo íst' o kvázisprávny akt, s výnimkou prípadu, že by rozhodovacím orgánom bola entita s vrchnostenskou mocou ${ }^{25}$ (najmä orgán dohl'adu, poznámka autora). V tejto veci zastávame v našich právnych podmienkach opačné stanovisko. Skutočnost', že v ZoCP ani v inom právnom predpise nie je osobitne verejnoprávne procesne riešené rozhodnutie valného zhromaždenia o práve výkupu, neznamená, že tento orgán nerozhoduje o právach (a súčasne povinnostiach) dotknutých akcionárov na základe zákonného mandátu zvereného mu na tento

23 GLÉZL - JABLONKA - PATAKYOVÁ, Úprava práva výkupu (squeeze-out) v slovenskom práve (dodržanie princípu efektívnosti komunitárneho práva a ústavné aspekty práva výkupu), s. 228. Užáková považuje nastavenie slovenskej právnej úpravy v znení do 31. decembra 2018 za striktné a z toho dôvodu za málo využívané. Pozri UŽÁKOVÁ, Constitutional and Legal Aspects of Squeeze-out of Minority Shareholders, s. 963.

24 Rok 2007: 1, rok 2008: 1, rok 2012: 2, rok 2014: 1, rok 2018: 1. Spracované podla údajov zo Správ o výkone činnosti útvaru dohl'adu nad finančným trhom za roky 2007 až 2018. Dostupné na www.nbs.sk.

25 HAVEL, Vyvlastnění, vytlačení akcionářủ a ústavnost, s. 218-219. 
účel. Na tomto nemení nič ani to, že rozhodnutie si vo valnom zhromaždení presadí majoritný akcionár bez hlasov ostatných akcionárov, čím fakticky rozhoduje sám o svojom práve. $\mathrm{V}$ právnom poriadku existuje viacero analogických prípadov, $\mathrm{v}$ ktorých zákon zveril kompetenciu súkromnoprávnemu subjektu rozhodovat' o právach a povinnostiach iných osôb (napríklad rozhodcovské súdy, ktorých zriad'ovatel'om mohli byt' ešte donedávna samotné strany sporu).

Výnimočným je v tejto súvislosti založenie kompetencie viest' osobitné správne konanie (podl'a zákona č. 747/2004 Z. z. o dohl'ade nad finančným trhom a o zmene a doplnení niektorých zákonov v znení neskorších predpisov; d’alej len ,zákon č. 747/2004 Z. z.“) pre akciovú spoločnost', ktorou je burza cenných papierov. ${ }^{26}$ Tá môže v tomto konaní rozhodnút' (prostredníctvom predstavenstva, ktorého zloženie odzrkadl'uje akcionársku štruktúru burzy) napríklad o pozastavení obchodovania alebo o vylúčení cenných papierov z trhu burzy aj v prípade vlastného akcionára. Nejde síce o prechod vlastníckeho práva, ale o obmedzenie ius disponendi určitým spôsobom, predsa len dochádza k limitácii vlastníckeho práva.

Na základe toho by sme mohli dospiet' k záveru, že i orgán akciovej spoločnosti je kvázi orgánom verejnej moci, avšak bez výslovného zakotvenia verejnoprávneho procesného postupu a súdneho prieskumu jeho aktov a činnosti ( $\mathrm{z}$ tohto dôvodu tak nepôjde o orgán verejnej správy). ${ }^{27}$ Je namieste otázka, či je vôbec potrebný osobitný administratívnoprávny postup, ked’že ZoCP vyžaduje vel'mi konkrétne a jednoznačné podmienky na realizáciu squeeze-outu. $\mathrm{V}$ takom prípade je rozhodovanie valného zhromaždenia a jeho uznesenie ${ }^{28}$ založené obdobne ako u orgánu verejnej moci na simplifikatívnom skúmaní zákonných predpokladov bez d'alšieho hlbšieho skúmania, zdôvodňovania a správnej úvahy. Naplnenie zákonných predpokladov následne založí nárokovatel'nost' squeeze-outu zo strany väčšinového akcionára zjednodušene tak ako napríklad u žiadatel'a o bankové povolenie.

Po nadobudnutí účinnosti zavedenia práva výkupu v SR by sme mali nahliadat' na tento inštitút ako na aplikáciu práva vyplývajúceho zo zákona, nie ako na vyvlastnenie.

Jednou z diskutovaných otázok právnej úpravy je aj stanovenie spravodlivej ceny (primeranej náhrady) pre výkup akcií. Nevýhoda postavenia menšinových akcionárov v právnej úprave práva výkupu do 31. decembra 2018 spočívala v tom, že nemohli návrh na uzavretie zmluvy o kúpe akcií fakticky účinne odmietnut'. Ich prejav vôle bolo možné v prípade neprijatia návrhu rozhodnutím súdu nahradit'. V konaní o nahradení prejavu vôle mohli namietat' iba neprimeranost' ponúknutého protiplnenia. Po 1. januári 2019 sa síce právny stav zmenil z režimu prevodu na režim prechodu, ale minoritní akcionári nad'alej nemôžu zvrátit' uplatnenie vytesnenia, iba namietat' neprimeranost' protiplnenia. Ked'že ide o nútené a neodvratné odobratie majetku, „cena by mala zodpovedat' tzv. absolútnemu odškodneniu, $t$. j. takej hodnote akcií, aby vytesnený akcionár mohol za ziskané protiplnenie nadobudnút' alternatívnu investíciu s rovnakým výnosom i rizikom. " ${ }^{29}$ Tento názor - nech je už akokol'vek teoreticky správny - sa nám javí, hlavne v podmienkach slovenského kapitálového trhu, ako idealistický. Smernica o ponukách prevzatia hovorí o tzv. primeranej cene, pričom za primeranú považuje protihodnotu v povinnej ponuke na prevzatie

\footnotetext{
26 Pozri § 65 a 65a zákona č. 429/2002 Z. z. o burze cenných papierov v znení neskorších predpisov.

27 Súkromná správa, napríklad správa obchodnej spoločnosti, je zo súdneho prieskumu v rámci správneho súdnictva vylúčená. Pozri SEMAN, T.: Verejná správa v správnom súdnictve. Košice : Univerzita Pavla Jozefa Šafárika v Košiciach, 2016, s. 11. ISBN 978-80-8152-424-0. Na druhej strane v právnej úprave poznáme inštitút nútenej správy dohliadaných akciových spoločností, ktorá nie je výlučne správou súkromnou. Súdny prieskum postupu núteného správcu prichádza do úvahy, ak ide o zamestnanca orgánu dohl'adu (napríklad v ČR).

28 Čech uvádza, že uznesenie je rozhodnutím, ktoré samo o sebe zakladá právny dôvod prechodu práv k dotknutým cenným papierom na hlavného akcionára. Pozri ČECH, K (četným) problémům právní úpravy výkupu účastnických cenných papírů (squeeze-out), s. 659.

29 HEČKOVÁ - CHAPĆÁKOVÁ, Explikácia významu inštitútu Squeeze Out v podmienkach Slovenskej republiky, s. 429.
} 
a v dobrovol'nej ponuke pri dosiahnutí aspoň $90 \%$ podielu na akciách spojených s hlasovacím právom. V ostatných prípadoch dobrovol'nej ponuky smernica neurčuje spôsob stanovenia ceny. ZoCP v $\S 118 \mathrm{i}$ ods. 10 ustanovuje, že sa postupuje ako pri určovaní ceny akcií v povinnej ponuke, t. j. určenie znaleckým posudkom pri dodržiavaní referenčných mantinelov, aby nedošlo k podhodnoteniu. Uvedené určovanie ceny sa osvedčilo a nebolo zmenené novou právnou úpravou § 118i ZoCP ani po 1. januári 2019.

Zmena spočíva v ustanovení povinnosti predstavenstva akciovej spoločnosti vyjadrit' sa k primeranosti navrhovanej výšky protiplnenia pre minoritných akcionárov. Obsah vyjadrenia musí byt' pritom zaznamenaný v pozvánke na zasadnutie valného zhromaždenia, ktoré bolo zvolané za účelom prijatia rozhodnutia o prechode akcií (uplatnení práva výkupu).

Zachovanie súdnej ochrany v otázke skúmania primeranosti ceny považujeme za kl'účové pri posudzovaní primeranosti zásahu do práv zostatkových akcionárov. Musíme tiež konštatovat', že „odškodnenie“ formou vyplatenia primeranej ceny nezohl'adňuje inú ujmu nemajetkovej povahy, ktorú vytlačený akcionár utrpí, najmä ak ide o konanie proti jeho vôli (má záujem na zotrvaní v investícii z rôznych vy̌šsie uvedených dôvodov).

Možno sa stotožnit's názorom, podl'a ktorého je inštitút vytesňovania v Európe už bežným a legitímnym právnym nástrojom pre realizáciu zmien vo vlastníckej štruktúre (verejných) akciových spoločností. Kritické názory podl'a neho nenazerajú na inštitút vytesňovania $\mathrm{z}$ pohl'adu väčšinových akcionárov $\mathrm{v}$ kontexte zabezpečenia efektívnosti ekonomického systému a poukazujú na rozpor so všeobecnými princípmi ochrany vlastníctva a menšinových práv. ${ }^{30}$

Podl'a nášho názoru však nemožno oddelene skúmat' a zvažovat' ekonomickú podstatu tohto inštitútu a predovšetkým prostredie jeho realizácie (verejný kapitálový trh) od jeho právnej legitimity. V nadväznosti na to poukazujeme na dve skutočnosti, ktoré sa v ostatnej odbornej literatúre opomínajú.

Po prvé, kapitálový trh je trhom rizikovým, na ktorom vystupujú jeho účastníci ako kvalifikovaní investori. Regulovaný trh finančných nástrojov (vrátane našich podmienok obchodovania na trhu Burzy cenných papierov v Bratislave, a. s.) neumožňuje investorom nakupovat'/predávat' investičné tituly priamo, ale iba prostredníctvom na to oprávnenej osoby - profesionála (obchodník s cennými papiermi alebo investičná banka), ktorá je povinná u zákazníka (nekvalifikovaného investora) pred poskytnutím investičnej služby nákupu/predaja zrealizovat' test vhodnosti, ktorý sa týka posúdenia rizikovej averzie klienta, čo vyplýva priamo z právneho poriadku (§ 73f ZoCP), prípadne test primeranosti ( $\$ 73 \mathrm{~g} \mathrm{ZoCP})$.

Po druhé, kúpa akcií verejných akciových spoločností na kapitálovom (regulovanom) trhu v menšom množstve je špekulatívnou investíciou (s výnimkou schém fondového financovania s dlhodobou investičnou stratégiou) so sledovaním dosiahnutia jednorazového výnosu v krátkodobom horizonte $\mathrm{z}$ kolísania trhovej ceny akciového titulu, bez záujmu o proces riadenia spoločnosti, ktorý prakticky ani nie je možný. ${ }^{31}$ Tieto skutočnosti, opomínané odbornou literatúrou (zrejme $\mathrm{z}$ dôvodu profilácie na výlučne právne problémy), podla nás posúvajú vnímanie práva výkupu z hl’adania jeho akademickej (teoretickej) spravodlivosti pri vyvažovaní záujmov väčšiny s menšinou do ekonomickej reality kapitálového trhu a jeho podstaty (ako formálneho prameňa práva). Možno tu tak identifikovat' aj iné - verejnoprávne - nástroje ochrany akcionára (ako klienta poskytovatel'a investičnej služby) a súčasne vnímat' určitú mieru „degradácie“ vlastníckeho práva drobného investora, ktorý neotvára pozíciu

30 HOLUB, D.: Právo cenných papierov. Bratislava : IURA EDITION, 2013, s. 119. ISBN 978-80-8078-562-8. Obdobne HAVEL, Vyvlastnění, vytlačení akcionářu a ústavnost, s. 219.

31 Zjednodušene možno povedat', že zatial' čo menšinový akcionár je iba investorom, väčšinový akcionár je investorom, ktorý aktívne riadi emitenta a aktívne tak zvel'ad’uje svoju investíciu. Uspokojuje teda nielen svoju majetkovú potrebu, ale aj „duševnú“ víziu podnikania. 
s výhl'adom na dlhšie obdobie, ${ }^{32}$ oproti vlastníctvu majoritného investora, ktorý nakupuje akcie vo vel'kom množstve so serióznym záujmom na d'alšom rozvoji akciovej spoločnosti.

\section{Zhodnotenie recentnej právnej úpravy squeeze-outu a podnety na jej doplnenie (v záujme ochrany minoritných akcionárov)}

Nová právna práva $\S 118 \mathrm{i}$ ZoCP sa nevzt'ahuje v zmysle prechodného ustanovenia k úpravám účinným od 1. januára 2019 (nový § 173zc ZoCP) na právne vzt’ahy, ktoré sa týkajú práva výkupu vzniknutého pred 1. januárom 2019.

Dôležitým aspektom verejnoprávnej záruky práv menšinových akcionárov, najmä s ohl'adom na stanovenie primeranej ceny, je odobrenie práva výkupu orgánom dohl'adu nad finančným trhom (NBS). Do 31. decembra 2018 sa účinnost' práva výkupu viazala na právoplatné udelenie súhlasu NBS v konaní podl'a zákona č. 747/2004 Z. z. s procesnými špecifikami podl'a ZoCP. Od 1. januára 2019 uplatnenie práva výkupu voči zostávajúcim akcionárom (rovnako aj voči ich právnym nástupcom) podlieha udeleniu prechádzajúceho súhlasu NBS. Autor príspevku pri tvorbe návrhu nového znenia $\S 118 \mathrm{i}$ v novele ZoCP účinnej od 1. januára 2019 navrhol doplnit', aby sa s týmto predchádzajúcim súhlasom spájala aj absolútna neplatnost' každého právneho úkonu, ktorý bude vykonaný bez jeho udelenia, pričom neplatný bude aj každý úkon urobený na základe predchádzajúceho súhlasu udeleného na základe nepravdivých údajov (§ 159 ods. 3 v znení po 1. januári 2019). Schval'ovací proces NBS považujeme za dôležitú garanciu zákonného priebehu squeeze-outu, ktorý sa uplatní rozhodnutím valného zhromaždenia o prechode akcií zostávajúcich akcionárov na hlavného akcionára. V rámci neho totiž dochádza aj k preskúmaniu správnosti stanovenia ceny. Za určitú garanciu možno považovat' aj vlastné stanovenie prahu 95\% (oproti smernicou o ponukách prevzatia požadovaných $90 \%$ ).

Pri hl'adaní optimálneho modelu rozhodovania Užáková preferuje za najspravodlivejšie rozhodovanie o squeeze-oute súdom, ako alternatívu až následne rozhodovanie orgánom dohl'adu. ${ }^{33}$ Ako bolo uvedené, v prípade orgánu dohl'adu (NBS) by rozhodovací proces musel vychádzat' zo správnej úvahy, ktorej vol'nost' by sa dohliadací orgán snažil obmedzit' jednoznačnými zákonnými kritériami (napríklad dosiahnutím existujúcich percentuálnych podielov). Ak by explicitne kritériá upravené neboli, nároky na rozsah dokazovania by bol väčší, ked’že by sa rozhodovalo o proti sebe stojacich právach akcionárov tak, ako je to v kontradiktórnom konaní. Tento stav by posúval rozhodovanie orgánu verejnej správy na úseku dohl'adu nad kapitálovým trhom (dodržiavaním podmienok uplatnenia práva výkupu) do roviny súdnej ochrany práv, čo nemožno v našich podmienkach považovat' za úlohu orgánov verejnej správy. V zmysle $\S 2$ ods. 3 zákona č. 747/2004 Z. z. predmetom dohl'adu nad dohliadanými subjektmi nie je rozhodovanie sporov $\mathrm{z}$ právnych vzt'ahov medzi dohliadanými subjektmi a ich klientmi, na ktorých prejednávanie a rozhodovanie sú príslušné súdy alebo iné orgány podl'a osobitných predpisov (výkon dohl'adu vo verejnom záujme, judikovaný Súdnym dvorom EÚ v konaní C-222/04 Peter Paul a ostatní c/a SRN). Na druhej strane, v ČR o sporovej agende medzi finančnými inštitúciami a ich klientmi rozhoduje v správnom konaní správny orgán, ktorým je finančný arbiter.

Za nedostatok regulácie squeeze-outu na úrovni EÚ možno považovat' absenciu riešenia kolízie právnych režimov v prípade, ak sú akcie identického emitenta pripustené na

\footnotetext{
32 Výnimočne s ciel'om zneuživat' svoje akcionárske práva, čo možno považovat' tiež za určitý druh špekulácie. Podobnú argumentáciu používa osobitná čast’ dôvodovej správy k §118i ZoCP k zákonu č. 644/2006 Z. z., ktorá uvádza, že ,,môže dochádzat’ k tomu, že minoritni akcionári (držiaci symbolické podiely v spoločnosti, ktoré predstavujú niekol'ko kusov akcií z emisií o desiatkach či stovkách tisíc kusov) využivajú práva minoritných akcionárov za účelom získania výhod, ktoré sú v zjavnom nepomere voči ich účasti na kapitálovej spoločnosti, spôsobom ohrozujúcim zámery majoritného akcionára i spoločnost’ samotnú. Väčšinou ide o situácie, kedy záujmy minoritných akcionárov nespočívajú v dlhodobom vlastneni akcii a činnosti spoločnosti, ale skôr vo vyvíjani tlaku na majoritného akcionára. "

33 Pozri UŽÁKOVÁ, Zánik účasti akcionára v akciovej spoločnosti so zameraním na squeeze out, s. 113.
} 
obchodovanie na viacerých regulovaných trhoch $\mathrm{v}$ rozličných členských štátoch, prípadne aj na regulovaných a súčasne neregulovaných trhoch (multi-listing). V takom prípade vyvstáva otázka, podl'a ktorej z právnych úprav sa má postupovat' pri schval'ovaní uplatnenia práva výkupu. Máme za to, že táto situácia vyžaduje získanie všetkých príslušných verejnoprávnych súhlasov vo všetkých členských štátoch, kde je emisia pripustená na obchodovanie. Tento postup opätovne st’ažuje reálny výkon práva väčšinovým akcionárom $\mathrm{v}$ procese koncentrácie vlastníctva. Vo väzbe na to možno zvažovat' zavedenie jednotného povolenia platného $\mathrm{v}$ rámci celej EÚ/EHP, ktoré by značne zjednodušilo proces vytesnenia, analogicky ako v prípade cezhraničnej notifikácie dohliadaných subjektov finančného trhu. Za prekážku tejto iniciatívy považujeme národné právne režimy, ktoré sa medzi členskými štátmi diferencujú (najmä ustanovenie rozdielneho subjektu príslušného na rozhodovanie). $Z$ toho vyplýva potreba kompromisu členských štátov o subjekte, ktorý by o práve výkupu rozhodoval a ktorého rozhodnutie by považovali za dostatočnú garanciu menšinových akcionárov. Výzvou pre tento orgán by tak zostalo posudzovat' primeranost' ceny odkupovaných akcií, ked'že jej stanovenie by muselo byt' podrobené novému spôsobu jej výpočtu zohl'adňujúcemu trhový vývoj na regulovaných trhoch vo viacerých jurisdikciách.

Slovenská právna úprava rieši z pohl'adu orgánu dohl'adu detailnejšie iba výkon dohl'adu nad realizáciou ponuky na prevzatie $(\S 135 \mathrm{c}$ ZoCP), nie nad právom výkupu. Neopomína však možnost' sankcionovat' nedostatky v činnosti uplatňovatel'a práva výkupu spočívajúce $\mathrm{v}$ porušení povinností uložených zákonom (§ 144 ods. 5 ZoCP).

Ako sme uviedli, dôvodová správa k zákonu č. 373/2018 Z. z. (k § 118i) v sebe zahŕňa určitý pragmatizmus. Napriek zmieneným akademickým názorom, v zmysle ktorých sa javí teoreticky ako spravodlivejšia predchádzajúca právna úprava (do 31. decembra 2018), v rámci ktorej rozhodoval súd o nahradení prejavu vôle, išlo o vel'mi zložitý proces náročný na čas, identifikáciu ostatných akcionárov, vykazujúci náklady spojené so súdnym konaním (podávanie viacerých žalôb na rôzne miestne príslušné súdy $\mathrm{v}$ závislosti od počtu menšinových akcionárov). Nová právna úprava sl’ubuje väčšiu flexibilitu a tým aj zvýšenie atraktivity pre inštitút práva výkupu. Jeho využitel'nost' bude však nad'alej v podmienkach slovenského kapitálového trhu limitovaná množstvom akciových emisií na regulovanom trhu. Možno tak konštatovat' smerovanie k potenciálne vyššej efektivite.

Ak existenciou squeeze-outu pripúšt'ame, že možno nútit' malého investora hl'adat' novú investíciu, nedoriešenou podl'a nášho názoru ostáva otázka spravodlivosti jeho aplikácie v kolektívnych schémach investovania na finančnom trhu. ${ }^{34}$ Vhodným riešením by bolo vyňat' z pôsobnosti vytesnenia akcie držané vo fondoch kolektívneho investovania a dôchodkových fondoch (čl. 1 ods. 2 smernice o ponukách prevzatia ustanovuje iba výnimku, podl'a ktorej sa nevzt’ahuje - vrátane práva výkupu - na nimi emitované cenné papiere). Takou výnimkou by boli kolektívne schémy investovania zvýhodnené a prinieslo by to d’alšiu disproporciu $\mathrm{v}$ zaobchádzaní medzi akcionármi, tentoraz medzi menšinovými navzájom. Opätovne ale považujeme za potrebné zdôraznit' niektoré typické znaky kapitálového trhu, a to že kolektívne investovanie a dôchodkové sporenie (investovanie) sleduje osobitný verejný záujem štátu deklarovaný rôznymi zvýhodneniami, ktorým možno vyvážit' protichodné záujmy väčšinového akcionára.

Medzi existujúce zvýhodnenia investovania na kapitálovom trhu patrí v súčasnosti aj oslobodenie od dane z príjmu podla $§ 9$ ods. 1 písm. 1) zákona č. 595/2003 Z. z. o dani z príjmu v znení neskorších predpisov u dlhodobého investičného sporenia podl'a $\S 7$ ods. 11 ZoCP. Nejde pritom o kolektívne investovanie ale individuálne riadenie portfólia, v ktorom možno badat' obdobne určitý verejný záujem na dlhodobom investovaní. Vytesnenie tu

34 Na tento problém poukázala Užáková, tamtiež, s. 104. 
nepovažujeme za porušenie podmienok jeho zvýhodnenia, pretože portfólio sa môže operatívne obmieňat' (transakciami obchodníka s cennými papiermi) bez vyplatenia plnenia investorovi, tak ako u kolektívnych schém, aj ked' možno namietnut', že portfólio v kolektívnych schémach je predmetom spoluvlastníctva (napríklad podielnikov). V tejto súvislosti stojí za zváženie, či by potenciálna výnimka mohla byt' vztiahnutá aj na takéto zvýhodnené individuálne správy finančných nástrojov. Užáková dáva „,na zváženie, či neponechat' aj malým investorom možnost' zhodnocovat' svoje úspory (alebo zverené prostriedky) a prečo nepovažovat' možnost' dlhodobého investovania malými akcionármi (vrátane fondov) práve za pozitívum vo verejnom záujme. "35

Máme za to, že pri stanovení zmienenej výnimky pre kolektívne (prípadne individuálne investičné) schémy bude rozhodujúce stanovit' aj percentuálny podiel akcií $\mathbf{v}$ spoluvlastníctve u jedného subjektu kolektívneho investovania a dôchodkového sporenia (resp. vo vlastníctve jedného subjektu), kedy bude ešte squeeze-out možný, aby nedošlo k jeho úplnému znefunkčneniu u emisií v zvýhodnenej kolektívnej a individuálnej držbe. Otázka objektivizácie percentuálneho prahu sa zhl'adiska akcionárskej spravodlivosti relativizuje, pretože akcie rôznych emitentov majú rôznu hodnotu, a hodnota vlastníctva akcie jedného emitenta môže presahovat' hodnotu viacerých akcií u druhého emitenta. Zároveň investícia do akcie u jednej fyzickej osoby môže voptike jej majetkových pomerov predstavovat' vysoký náklad na úkor spotreby oproti majetnejšiemu investorovi. Kapitálový trh by tak prehíbil majetkové rozdiely medzi akcionármi navzájom, aj ked' kompenzované zvýhodnením kolektívnej správy aktív (ktorá má byt' preferovanou možnost'ou investovania pre drobných investorov).

Ako bolo spomenuté, právu výkupu predchádza realizácia ponuky na prevzatie. Ponuku na prevzatie zákon vyžaduje aj u iných právnych situácií (pozri § 170 ods. 3 v spojení s $§ 119$ ZoCP) ako je nadobudnutie vlastníctva $\mathrm{k}$ určitému percentuálnemu podielu na akciách emitenta. Jednou $\mathrm{z}$ nich je to, že emitent sa môže rozhodnút', že s cennými papiermi sa prestane obchodovat' na regulovanom trhu (alebo prijme iné rozhodnutie, ktoré má za následok, že sa s cenným papierom prestane obchodovat', napríklad o zmene zaknihovanej podoby na podobu listinnú). Druhou situáciou je neplnenie si zákonných informačných povinností emitenta, $\mathrm{v}$ dôsledku ktorého dochádza $\mathrm{k}$ ich vylúčeniu $\mathrm{z}$ obchodovania na regulovanom trhu (prípadne môže íst' o iné podobné skutočnosti, ktoré majú za následok takéto vyradenie $\mathrm{z}$ regulovaného trhu). Ide o situácie riadeného going private (premeny na súkromnú akciovú spoločnost'). Môže tak nastat' situácia, ktorú emitent (ovládaný väčšinovým akcionárom) úmyselne vyvolá, aby sa zbavil menšinových akcionárov cestou realizácie práva výkupu. Majoritný akcionár však svoje právo na odkup nemusí využit' a v rukách ostatných akcionárov zostanú fakticky nepredajné akcie, ktoré stratili svoje „atraktívne vlastnosti“; delistingom totiž prestanú byt' akcie investične zaujímavé a ich trhová cena už nie je a) likvidná, b) reálne vypovedajúca o ich hodnote, čím minoritný akcionár stráca predstavu o ich reálnej hodnote. To možno považovat' za dôvod, aby sa regulácia squeeze-outu rozšírila aj na neregulované obchodné platformy (napríklad mnohostranný obchodný systém - MTF), čím by sa umožnilo zostatkové akcie predat'. Prípady, ked' dôjde k vylúčeniu akcií kvôli neplneniu si informačných povinností, je možné sanovat' zásahom orgánu dohl'adu ako ultima ratio, a to uložením nápravného opatrenia v sankčnom konaní vedenom proti emitentovi, ktoré by spočívalo v prinavrátení emisie akcií na regulovaný trh (opätovné podanie žiadosti o prijatie na obchodovanie), aj ked' si uvedomujeme problematickost' núteného výkonu takého rozhodnutia.

35 Tamtiež, s. 115. 
Ďalším dôvodom zavedenia práva výkupu i pre tieto obchodné miesta môže byt' snaha o riešenie pozostatkov obdobia kupónovej privatizácie, aj ked' pravdepodobne väčšina emisií z týchto čias bude bezcenná a akcionári sú bagholdermi (držitel’mi bezcenných akcií).

\section{ZÁVER}

Právo výkupu bolo v rámci procesu jeho implementácie diskutované ako pomerne kontroverzné riešenie majetkových pomerov vo verejnej akciovej spoločnosti. Na základe analyzovaných názorov prichádzame k záveru, že za presne určených podmienok, pri vyplatení spravodlivej ceny a zabezpečení jej možného súdneho prieskumu by bolo možné squeeze-out označit' ako legitímny prostriedok koncentrácie akcií. Ako však postupovat', ak minoritný akcionár nechce predat' svoju majetkovú účast'. O to viac to platí v období trendu trhového rastu ceny na akciových trhoch (slovenský akciový trh je v tomto skôr výnimkou $\mathrm{z}$ dôvodu nízkej likvidity a tendencie st’ahovania/delistingu akcií z jeho obchodného miesta). Logika minoritných akcionárov je konzistentná s teóriou „príživníkov“, ako uvádza Shiller vo svojej revolučnej práci „Irrational Exuberance“.36 Možno ju pripodobnit' zaužívanému pojmu „free rider", 37 aj ked” ten vychádza iba zo „zvezenia sa“ popri silnejších hráčoch (majoritných akcionároch), bez prínosu pre akciovú spoločnost', bez vyvinutia úsilia o jej správu (hoci platí zásada, že vlastníctvo zaväzuje). Teória „príživníkov“ znamená, že pokial' sa množstvo odborníkov a investorov zaoberá štúdiom ceny akcie a potvrdzujú ich zjavnú hodnotu, prečo márnit’ čas vlastnou snahou o zistenie primeranej ceny (= reálnej hodnoty trhovej kapitalizácie). Prečo sa nepriživit' na účet iných usilovných investorov a kopírovat' jednoducho ich investičné správanie. Existujú aj prípady, ked' minoritný akcionár vlastníctvo akcií zneužíva špekulatívnym spôsobom, ktorý nesleduje ani tak investičný mainstream ako skôr vytĺkanie čo najlepšej odkupnej ceny od majoritného akcionára. Zneužitie postavenia menšiny je extrémom na jednom z protipólov rovnováhy vlastníckych práv všetkých akcionárov v emitentovi. Držba akcií v rukách menšinového akcionára sa stáva krátkodobou špekuláciou za účelom dosiahnutia najlepšej ceny od väčšinového akcionára, ${ }^{38}$ nie cestou predaja verejne prístupnej investície iným investorom na kapitálovom trhu. Zastávame názor, že tento fenomén je typický najmä pre menej likvidné akciové trhy tak, ako to je v Slovenskej republike. Ponechanie malej investície môže mat' aj iné dôvody (hrdost', tradícia vlastníctva akcií lokálneho emitenta, ako napr. regionálne podniky). Paradoxne práve nevôl'a predat' akcie menšinou sa stáva dôvodom faktickej nelikvidity emisie a trhu, na ktorom sa obchoduje. Krajným riešením je pre väčšinového akcionára dobrovol'né opustenie alebo porušením informačnej povinnosti vyvolané vylúčenie $\mathrm{z}$ trhu, čo je v konečnom dôsledku pre prečistenie trhu pozitívne (pri dostatočnom množstve emisií obchodovaných na regulovanom trhu). Takým situáciám by právo výkupu mohlo predchádzat’ ako ex ante nástroj.

Otvorený zostáva problém minoritných akcionárov, ktorých kapitál premenený na akcie je koncentrovaný $v$ schémach kolektívneho investovania. Aby sa ul'ahčila aktivita a informovanost' akcionárov investujúcich prostredníctvom správcov ich aktív o emitentoch, sú členské štáty EÚ povinné zabezpečit' transpozíciu smernice Európskeho parlamentu a Rady (EÚ) 2017/828 zo 17. mája 2017, ktorou sa mení smernica 2007/36/ES, pokial ide o podnietenie dlhodobého zapojenia akcionárov, a to do 10. júna 2019. Aj ked' táto smernica nerieši problém ich vytesnenia, má zabezpečit' aspoň príležitost' na efektívny výkon akcionárskych práv týchto akcionárov prostredníctvom správcov aktív. V článku sme v tejto

\footnotetext{
36 SHILLER, R. J.: Investiční horečka - iracionální nadšení na kapitálových trzích : Predhovor k prvému vydaniu. Praha : Grada Publishing, a. s., 2010, s. 18-19. ISBN 978-80-247-2482-9. (Český preklad).

37 UŽÁKOVÁ, Constitutional and Legal Aspects of Squeeze-out of Minority Shareholders, s. 964.

38 Užáková v tejto súvislosti používa označenie „professional trouble-makers“. Tamtiež.
} 
súvislosti uviedli niektoré návrhy, ktoré by mohli kolektívne schémy preferovat' pred záujmami väčšinového akcionára.

\section{KLUÚČOVÉ SLOVÁ}

právo výkupu, ponuka na prevzatie, Národná banka Slovenska, vyvlastnenie, primeraná cena, rozhodujúci orgán

\section{KEY WORDS}

Squeeze-out/Buy-out, Take Over Bid, National Bank of Slovakia, Expropriation, Fair Price, Decision-making Authority

\section{POUŽITÁ LITERATÚRA}

1. BUCK-HEEB, P.: Kapitalmarktrecht. 2. Auflage. Heidelberg : C. F. Müller Verlag, 2007. ISBN 978-3-8114-8055-1.

2. ČAVOJSKÝ, P.: Základné princípy právnej úpravy ponuky na prevzatie podielu na majetkových cenných papieroch podl'a 13. smernice. In: Právny obzor, roč. 87, 2004, č. 3.

3. ČECH, P.: K (četným) problémům právní úpravy výkupu účastnických cenných papírů (squeeze-out). In: Právní rozhledy, 2005, č. 18.

4. ČUNDERLÍK, L. a kol.: Právo finančného trhu. Bratislava : Wolters Kluwer, s.r.o., 2017. ISBN 978-80-8168-753-2.

5. DOLEŽIL, T. - HAVEL, B.: Squeeze-out trochu jinak. In: Jurisprudence, roč. XIV, 2005, č. 8.

6. GLÉZL, A. - JABLONKA, B. - PATAKYOVÁ, M.: Úprava práva výkupu (squeeze-out) v slovenskom práve (dodržanie princípu efektívnosti komunitárneho práva a ústavné aspekty práva výkupu). In: Vzájemné ovlivňování komunitární úpravy českého a slovenského obchodního práva na pozadí procesu jejich reforem : Sborník ze setkání kateder obchodního práva právnických fakult České republiky a Slovenské republiky. Praha : Univerzita Karlova v Praze, Právnická fakulta, 2007.

7. HAVEL, B.: Vyvlastnění, vytlačení akcionářù a ústavnost. In: Právní rozhledy, 2006, č. 6.

8. HEČKOVÁ, J. - CHAPČÁKOVÁ, A.: Explikácia významu inštitútu Squeeze Out v podmienkach Slovenskej republiky. In: Ekonomický časopis, roč. 57, 2009, č. 5.

9. HOLUB, D.: Právo cenných papierov. Bratislava : IURA EDITION, 2013. ISBN 978-808078-562-8.

10. KADUCH, B.: Vývoj úpravy squeeze-out v Polsku a poznámky k transpozici směrnice o nabídkách převzetí. In: Dny veřejného práva : Sborník př́íspěvků z mezinárodní konference. Brno: Masarykova univerzita, 2007.

11. KOTÁSEK, J.: Vytěsnění anonymního akcionáře. In: Časopis pro právní vědu a praxi, roč. XIV, 2006, č. 3.

12. LANGENBUCHER, K.: Aktien- und Kapitalmarktrecht. 2. Auflage. München : Verlag C. H. Beck, 2011. ISBN 978-3-406-62494-0.

13. SEMAN, T.: Verejná správa v správnom súdnictve. Košice : Univerzita Pavla Jozefa Šafárika v Košiciach, 2016. ISBN 978-80-8152-424-0.

14. SHILLER, R. J.: Investiční horečka - iracionální nadšení na kapitálových trzích : Predhovor k prvému vydaniu. Praha : Grada Publishing, a. s., 2010. ISBN 978-80-2472482-9. (Český preklad).

15. UZSÁK, M.: Co se o squeeze-out(u) nepíše. In: Bulletin advokacie, 2007, č. 3. 
16. UŽÁKOVÁ, V.: Constitutional and Legal Aspects of Squeeze-out of Minority Shareholders. In: Míl'niky práva v stredoeurópskom priestore 2012 : Zborník príspevkov z medzinárodnej konferencie. Bratislava : PraF UK, 2012.

17. UŽÁKOVÁ, V.: Zánik účasti akcionára v akciovej spoločnosti so zameraním na squeeze out : Dizertačná práca. 2017.

18. https://www.nrsr.sk/web/Default.aspx?sid=zakony/zakon\&MasterID=6986.

19. www.nbs.sk.

\section{KONTAKTNÉ ÚDAJE AUTORA}

doc. JUDr. L’ubomír Čunderlík, PhD.

docent na Katedre finančného práva

Právnická fakulta Univerzity Komenského v Bratislave

Šafárikovo námestie č. 6, P. O. BOX 313, 81000 Bratislava 1

Telefón: +421290129217

E-mail: lubomir.cunderlik@ flaw.uniba.sk 